\title{
Adherence of adult Chronic Kidney Disease patients with regard to their dialysis, medication, dietary and fluid restriction
}

\author{
*Geldine Chironda G., ${ }^{1,2}$, Bhengu B. ${ }^{3}$, Manwere A. ${ }^{4}$
}

\begin{abstract}
Objective: Chronic Kidney Disease (CKD) has become a major health problem as a result of complicated interrelationships with diabetes mellitus, hypertension and other associated diseases. Effective management of CKD depends on patient's adherence to their dialysis plan, medications, dietary and fluid restrictions. This study aimed at systematically reviewing the adherence of adult Chronic Kidney Disease (CKD) patients with regard to their dialysis, medication, dietary and fluid restriction.
\end{abstract}

Methods: Key words were used for the search in various data bases: "adherence", "Chronic Kidney Disease", "dialysis", "medication", "dietary" and "fluid restriction". Online data bases namely Medline, PubMed, Ebsco Host, CINAHL, google scholar and grey literature were used to identify published research from 1993 - 2016. Forty three (43) articles were identified regarding adherence of CKD patients to dialysis, medication, dietary and fluid restriction.

Results: Medication non adherence ranged from 3 to $80 \%$ through self-report, structured interview and biological markers. Fluid non-adherence was $10-74 \%$. Using self-report and biological markers, nonadherence to diet was $2-39 \%$ and $19-57 \%$ respectively. With regards to dialysis, skipping and shortening hemodialysis adherence ranged from $2.5 \%-19 \%$ and $20.3 \%-32.3 \%$ respectively. Globally, adherence rates to CAPD are not well documented in literature.

Conclusion: Non-adherence to dialysis, medication, dietary and fluid restriction is an area of concern internationally in CKD population. Furthermore, non-adherence rates are not well researched and documented in African literature. Therefore, Nephrology professionals in clinical practice are agents of improving adherence of CKD patients to ensure effective management of the disease.

Keywords: Adherence and non-adherence to medication, fluid, diet and dialysis, Chronic Ambulatory Peritoneal Dialysis (CAPD), Chronic Kidney Disease (CKD) and hemodialysis.

\footnotetext{
*Correspondence author: Geldine Chironda, Email: gerrychironda@yahoo.co.uk

${ }^{1}$ School of Nursing and Midwifery, University of Rwanda, Rwanda.

${ }^{2}$ Rory Meyens College of Nursing, New York University, New York, USA.

${ }^{3}$ School of Nursing and Public Health, Howard College Campus, University of KwaZulu-Natal, Durban, South Africa.

${ }^{4}$ Faculty of Health Sciences, Bindura University of Science Education, Bindura, Zimbabwe.
} 


\title{
Adhésion de patients adultes atteints de maladie rénale chronique en ce qui concerne leur dialyse, leurs médicaments, leur régime alimentaire et leur restriction
}

\author{
*Geldine Chironda G. ${ }^{1,2}$, Bhengu B. ${ }^{3}$, Manwere A. ${ }^{4}$
}

\begin{abstract}
Resume
Objectif: La CKD est devenue une menace majeure pour la santé en raison d'interactions compliquées avec le diabète sucré, l'hypertension et d'autres maladies associées. La prise en charge efficace de l'affection dépend des patients adhérant à leur plan de dialyse, de médicaments, de restrictions alimentaires et fluides, mais il s'agit d'un problème omniprésent. L'étude visait à revoir systématiquement l'adhésion des patients adultes atteints de maladie rénale chronique (CKD) en ce qui concerne leur dialyse, les médicaments, les restrictions alimentaires et de liquide.
\end{abstract}

Méthodes: Les mots clés suivants ont été utilisés pour la recherche: l'observance, la maladie rénale chronique, la dialyse, la médication, la restriction alimentaire et la restriction des fluides. La recherche a identifié 47 articles qui quantifient 1 'adhérence des patients CKD à la dialyse, à la médication, à la restriction alimentaire et à la restriction des fluides.

Résultats: La non-adhésion aux médicaments variait de 3 à $80 \%$ grâce à l'auto-évaluation, à l'entrevue structurée et aux marqueurs biologiques. La non-adhésion fluide de 30-74\% en utilisant l'auto-rapport et de 10 à $60 \%$ sur la base d'un gain de poids interdialytique inapproprié. À l'aide de marqueurs biologiques et d'auto-évaluation, la nonadhésion à l'alimentation était respectivement de 2 à $39 \%$ et de 19 à $57 \%$. En ce qui concerne la dialyse, le saut et le raccourcissement de l'hémodialyse ont varié respectivement de 2,5\% à $19 \%$ et de 20,3\% à 32,3\%. Globalement, les taux d'adhésion à la CAPD ne sont pas bien documentés dans la littérature.

Conclusion: Des preuves documentées ont révélé une non-adhésion à la dialyse, aux médicaments, à la restriction alimentaire et à la restriction des fluides, un domaine de préoccupation international dans la population à CKD. En outre, les taux de non-adhérence ne sont pas bien étudiés et documentés dans la littérature africaine. Par conséquent, les professionnels de néphrologie et / ou de soins intensifs dans la pratique clinique sont des défenseurs d'améliorer l'adhésion des patients de CKD pour assurer la gestion efficace de la maladie.

Mots-clés: Adhérence et non-adhérence aux médicaments, aux fluides, à l'alimentation et à la dialyse, à la dialyse péritonéale ambulatoire chronique (CAPD), à la maladie rénale chronique (ERC) et à l'hémodialyse.

\footnotetext{
* Correspondance auteur: Geldine Chironda, Email: gerrychironda@yahoo.co.uk

${ }^{1}$ School of Nursing and Midwifery, University of Rwanda, Rwanda.

${ }^{2}$ Rory Meyens College of Nursing, New York University, New York, USA.

${ }^{3}$ School of Nursing and Public Health, Howard College Campus, University of KwaZulu-Natal, Durban, South Africa.

${ }^{4}$ Faculty of Health Sciences, Bindura University of Science Education, Bindura, Zimbabwe.
} 


\section{INTRODUCTION}

Chronic Kidney Disease (CKD) affects individuals and health systems in low, middle and high income countries (1) and the global prevalence is estimated at 5 to $10 \% \%$ (2). CKD is also common in Africa although very limited data is collected on prevalence. Moreover, there are no reliable statistics about prevalence of CKD in all African countries due to lack of registries. The available data reveals consistent increase in the incidence of newly diagnosed individuals with CKD with a prevalence of about $10 \%(3,4)$.

CKD is deterioration in kidney function that results in kidney's inability to eliminate waste products, maintain acid base, fluid, and electrolyte balance (5). The disease progression starts with acute kidney injury, which is rapid loss of renal function over hours to a few days, resulting from ischaemic or toxic injury to the kidney causing retention of nitrogenous wastes (6). Untreated acute kidney injury will progress to $\mathrm{CKD}$, an irreversible condition (7) with persistent decrease in estimated Glomerular Filtration Rate (GFR) for at least 3 months (8) and continuous albuminuria which increases gradually from mild to severe levels (9).

According to Kidney Disease International Guidelines Organisation(KDIGO) CKD Work Group (9), the progression is from normal glomerular filtration rate (GFR) of $>90 \mathrm{ml} / \mathrm{min} / 1.73 \mathrm{~m}^{2}$ (stage 1) to mild impairment (GFR 60-90ml $/ \mathrm{min} / 1.73 \mathrm{~m}^{2}$ ) (stage 2), then moderate impairment (GFR $30-59 \mathrm{ml} / \mathrm{min} / 1.73 \mathrm{~m}^{2}$ ) (stage 3 ) leading to severe impairment (GFR $15-29 \mathrm{ml} / \mathrm{min} / 1.73 \mathrm{~m}^{2}$ ) (stage 4). Ultimately, it leads to CKD stage 5 (Morton \& Fontaine, 2009) which is complete failure of the kidneys to function at a level that is necessary for day-to-day life and kidney function less than $15 \%$ of normal GFR (9).

Integrated management of CKD puts emphasis on dialysis, medication, and dietary and fluid restriction. Individuals with CKD have comorbid conditions namely diabetes mellitus and hypertension which contributes to more than $36 \%$ and $24 \%$ of cases of ESRD respectively (4) as well as an increased risk of developing complications that affect all systems of the body. Other causes of CKD includes glomerulonephritis, interstial nephritis, congenital malformations, genetic disorders and obstructive uropathy (4). Therefore, medication is needed to manage comorbid and other conditions associated with CKD conditions as this slows the progression of CKD to end-of-life stages (10).

Similarly, nutritional therapy in CKD minimises uremic and anaemia symptoms, reduce the incidence of fluid, electrolyte and acid base imbalances, reduce patient's vulnerability to infections and limit catabolism (11). Moreover, removal and control of excess fluid is the cornerstone of volume management in CKD patients (12) as this prevent fluid overload. More importantly, Renal Replacement Therapy (RRT) is essential for management of advanced CKD and encompasses Chronic Ambulatory Peritoneal Dialysis (CAPD), haemodialysis and renal transplant (13). Chronic peritoneal dialysis and haemodialysis are dialytic therapies which remove toxins; solutes and fluid from blood through three principal mechanisms namely osmosis, diffusion and filtration (14).

In this regard, patients' adherence to dialytic procedures, medications, dietary and fluid restrictions is paramount in proper management of CKD population. Yet, low adherence to dialysis, medication, diet and fluid control is evident in more than half of the patients treated for CKD (15). Furthermore, patients with CKD need to cope with dependence in performing activities of daily living such as detrimental physical symptoms, limitations in dietary and fluid intake, changes in body image, work and a crippled economic status (16). The end result of these challenges is a cause of changed normal routines hence prediction of their control over treatment is difficult (18). Although the available literature still indicates problems of adherence among CKD population, little or no summative reviews that document and quantify adherence in four modalities namely dialysis, medication, fluid and dietary restriction exist. . Therefore, this systematic literature review aims to document and quantify the level of adherence to dialysis, fluid, diet and medication from the results of previous studies and to identify instruments and methods of measuring adherence among CKD adult population.

\section{MATERIALSAND METHODS}

A conclusive literature search was conducted to identify studies that quantify adult CKD patient's adherence to medication, diet, fluid intake and dialysis. The following data bases were used to find the research articles: Medline, PubMed, Ebsco Host, CINAHL, google scholar and grey literature. The key words used for the search were: adherence, Chronic Kidney Disease, dialysis, medication, dietary and fluid 
restriction. The inclusion criteria included all research articles from 1993 to 2016. Included also in the review were quantitative articles written in English that accurately indicate and quantify the rate of adherence to medication, diet, fluid intake and dialysis among adult CKD population. Excluded in the review were qualitative articles, articles with pediatric adherence $(<18)$, intervention studies and case studies. Duplicates were also excluded after critical review by two independent reviewers. Figure 1 shows a flow chart of the search strategy for identified articles.

\section{RESULTS}

Overall, there were forty three (43) articles identified from the comprehensive search on CKD adherence. Operational definition of adherence was highlighted. Instruments and methods of measuring adherence in CKD population were also revealed. Moreover, studies that quantify adherence rates to dialysis, medication, fluid and diet control were identified. Of the forty three articles, seven (7) were identified for dialysis adherence, nine (9) were for medication adherence, 14 articles were for fluid adherence and 13 articles were for dietary adherence. The results of the review are presented as follows:

\section{Adherence}

Cramer et al (17) defined adherence as following the recommendations made by the provider with respect to timing, dosage, and frequency of medication taking where the patient follows the prescribed interval and dose. The same author highlighted adherence as a measure implemented over a period of time in percentage form. Sabate (18) echoed the same sentiments and included person's behavior in taking medication, following a diet and making changes in lifestyle according with health professional recommendations. In this review, adherence was conceptualised as CKD patients' ability and behaviour to follow a dialysis plan, medication, diet and fluid restriction with respect to right timing, right dosage at prescribed intervals.

\section{Methods for measuring adherence in CKD patients}

The methods of measuring adherence to dialysis, medication, fluid and dietary restriction in CKD patients were identified. The identified methods of assessing adherence in CKD patients were: self-report, biological markers and

\section{Intradialytic Weight Gain (IDWG) (Table 1)}

\section{Instruments used in measuring adherence for CKD patients}

The instruments used in measuring adherence among CKD patients that have been developed and tested for use. The identified instruments include dialysis, diet and fluid nonadherence questionnaire (DDFQ) (19) and End Stage Renal Disease Adherence Questionnaire (ESRD: AQ) (20) which measures treatment adherence behaviors in four dimensions namely dialysis attendance, medication use, fluid restriction and diet recommendation (Table 2).

\section{Dialysis adherence}

Table 3 displays seven (7) studies identified for dialysis adherence. Sample size ranged from 40 in Turkey to 6251 in USA. The percentage of patients who are non-adherent through skipping varies from $2.5 \%$ in Turkey to $19 \%$ in USA $(21,22,23,24,25$, and 26) and through shortening from $20.3 \%$ to $32 \%$ in USA $(22,23)$. In a study from Africa, Zimbabwe showed non-adherence rate of $97.6 \%$ which was very high (27). On the contrary, non-adherence is virtually nonexistent in Japan and Sweden (25).

\section{Medication adherence}

Nine (9) studies revealed for medication adherence are shown in Table 4. Sample sizes ranged from 30 to 5478 and rates of medication non-adherence were measured using self-report. Non adherence to phosphate binders, antihypertensive, calcium supplements and vitamins ranged from $3 \%$ to $80 \%$, antihypertensive and phosphate binders from $21 \%$ to $73 \%$ and phosphate binders alone ranged from $17.4 \%$ to $24 \%(28,29,30,31,32,33,34$, and 35). Still, there are no documented adherence rates to medication in literature for African region

\section{Fluid adherence}

Table 5 shows fourteen (14) studies identified for fluid adherence of adult CKD patients and their non-adherence rates. The sample size ranged from 21 in the United Kingdom to 6251 in the USA. Self-report and intradialytic weight gain were used to measure fluid adherence in CKD participants. Non adherence using inter-dialytic weight gain ranged from $9.7 \%$ in USA to $70 \%$ in UK $(24,35,36,37$, $38,39,40,41,42,43,44)$. Through self-report, non-adherence to fluid intake ranged from $40.3 \%$ in China to $72 \%$ in Belgium $(19,45)$. Studies and 
documentation on adherence rates to fluid intake in African region were limited

\section{Dietary adherence}

There are thirteen studies selected for adult dietary adherence as shown in Table 6 . Sample size ranged from 62 in Hong Kong to 6251 in USA. In the case of potassium and phosphorus intake, dietary non-adherence is estimated at 2\% in USA to nearly $39 \%$ in Hong Kong (18, 22, 24, 32, 35, 42). Self-reported estimates of potassium and phosphorus intake ranged from $44 \%$ in Hong Kong to $81 \%$ in Belgium (19, 32, 46, 47). Protein non-adherence ranged from $4.5 \%$ in Iran to $77 \%$ in USA. In South Africa, self-reported non adherence to renal diet was $84 \%$ (36). Still, few documented published research studies on adherence rates in the African continent were found.

\section{DISCUSSION}

\section{Methods of measuring adherence}

Direct questioning and self-report instruments are most effective measures (19) if they are validated. The disadvantage of selfreport is bias as patients usually underestimate their non-adherence rates (48). Biochemical markers are also important in measuring adherence in CKD patients. However, they are influenced by many other variables such as residual urine volume, dialysis sessions and body weight. Nonetheless, the continual lack of accepted value for each biochemical marker gives doubt to reliability of the tools that assesses rates adherence in CKD population (35). For instance, potassium and phosphate values reflect residual renal function, dialysis adequacy and adherence with medication $(35,49)$ in addition to food intake $(50,51)$.

Studies have shown that Intradialytic Weight Gain (IDWG) is a valid and objective measure of fluid restriction assessment in patients with CKD $(24,49,52$, ) thus being widely used as an outcome measure $(50,52)$ in assessment of fluid restriction. Mean IDWG expressed as percent dry weight is one of the methods to measure fluid adherence (38). However, it is seen as an unfit measure since dry weight can only be estimated. Nevertheless, the researchers continue to agree that IDWG should be defined as a percentage of dry weight $(38,53)$. Furthermore, the point which defines fluid adherence is different in literature (54). However, research based practice states that IDWG should be less than $2.5 \mathrm{~kg}$ or $3.5 \%$ of dry body weight so as to reduce the excess fluid during dialysis sessions (53).

The disadvantage of biological markers is that they are influenced by many other variables such as residual urine volume, duration of dialysis session, the length of the intervals between 2 sessions and body weight. Nonetheless, lack of universally accepted cut off value for each marker raises the question of whether these measures are reliable tools to assess non adherence rates in CKD population (35). Potassium and phosphate values reflect not only food intake $(49,50)$ but residual renal function, dialysis adequate, time at which blood was taken for analysis between dialysis, acid base and hormonal status and adherence with medication $(32,35)$

\section{Instruments for measuring adherence}

There are differences in non-adherence rates due to lack of reliable instruments. Nevertheless, literature reveals two adherence scales that have been tested for use in patients with CKD. The dialysis, diet and fluid adherence instrument measures adherence to dialysis, fluid intake and dietary restrictions for the past two weeks (19). However, the weakness of DDFQ lies in not addressing medication use among CKD patients. Therefore measurement of adherence was limited. In view of this, Kim et al (20), developed an End Stage Renal Disease Adherence Questionnaire (ESRD: AQ) which measures adherence behaviors in four modalities namely; dialysis, medication, fluid restriction and dietary intake. Therefore, this instrument maybe used to measure adherence in all the four dimensions which encompasses the comprehensive care of patients with CKD.

\section{Adherence to medication, fluid, dialysis and diet in CKD patients}

Different rates of adherence are reported globally (Table 7). The non-adherence rates to dialytic procedures, medication, fluid and dietary changes ranges from $0-53 \%, 1.2-81 \%, 3.4-74 \%$ and $1.2-82.4 \%$ respectively $(21,24,28,32,35$, $36,37,38)$. This support documented evidence of poor adherence in all key aspects of integrated management among CKD patients. Dialysis has transformed the prognosis of patients with kidney disease but its effectiveness is unfortunately compromised by non-adherence (18). Because of the demands of haemodialysis, many patients do not adhere to the prescribed regimen there by jeopardising successful clinical outcomes. 
Inadequate adherence is common in CKD patients undergoing chronic haemodialysis and as many as $86 \%$ of the patients in the United Kingdom may be considered non-adherent to the treatment (17).

The availability of data that reveals adherence rates to haemodialysis of renal failure patients is lacking in all African countries. The study done by Chironda et al (27) showed nonadherence to haemodialysis of $97.6 \%$. This high rate of non-adherence in African countries is exacerbated by low socioeconomic status as most patients have no access to haemodialysis procedures and health insurance making care for CKD unaffordable (36). World Kidney Day (2012) echoed the same sentiments of CKD patients discontinuing dialysis due to limited economic resources in developing nations

Similarly, non-adherence to Peritoneal Dialysis (PD) dialysis procedure is scarce in literature although the dialytic procedure is available in all continents. Dean and Cruz (55) expressed the same sentiments and explained peritoneal dialysis as an inexpensive procedure which requires less infrastructure. Again, peritoneal dialysis is a convenient procedure which a patient can implement in their own homes. However, Lim et al (56) highlighted diminished and impairment of quality of life among patients on peritoneal dialysis. Griva et al (21) reveals the rates of non-adherence to Continuous Ambulatory Peritoneal Dialysis (CAPD) procedures ranged from 2.6-53\%. The same author highlighted that missed PD exchanges were reported to be in a range of $2.5-53 \%$, shortening by $4-15 \%$ of patients and performing less than $90 \%$ of prescribed exchanges was evident in $2-40 \%$ of patients. Indirect biochemical/ physiological measures reveals adherence rates at $74-78 \%$.

Medication non-adherence remains a major obstacle among patients with CKD. Individuals with CKD have comorbid conditions as well as an increased risk of developing complications that affect all systems of the body, are more likely to die from these complications than CKD. Diuretics, antihypertensive and antidiabetics are of importance and these drugs have proved to slow progression of CKD (11). Moreover, medications to manage pulmonary, gastrointestinal, neuromuscular, haematological, skeletal, integumentary and dietary intake alterations are needed (11). These medications can only work effectively if CKD patients are fully adherent with their treatment.
Prevention of fluid overload is the basis for fluid management in patients with CKD. Available literature indicates a daily fluid allowance of 0.5 litres in addition to the volume equal to daily urine output (12). Dietary sodium intake and medication containing sodium increase fluid overload (52) in patients with CKD. However, adequate dialysis removes excess fluid(57) in CKD patients. Therefore, effective fluid management in CKD population centres on dialysis, medication and dietary adherence.

Chronic Kidney failure needs dietary management in energy intake and nutrients to decrease morbidity and mortality (58). CKD patients should avoid high sodium and potassium diet to manage hypertension thereby decreasing the incidence of stroke. Furthermore, diet low in saturated fats is advised as evidence highlight this group of patients as high risk for development of coronary artery disease due to elevated levels of serum triglycerides and low high density lipoproteins (59).

\section{CONCLUSION}

Low adherence is of concern in CKD patients as previous studies reveal a greater number of patients deviating from dialysis, medication, fluid and dietary restrictions. There is need for more research and documentation of adherence rates among CKD patients especially in African countries. Controlling and managing the detrimental effects of CKD is the main focus. Therefore, the nephrology team which includes nephrologist, nurses, dieticians, social workers, dialysis technicians and pharmacists should implement a multidisciplinary approach in engaging CKD patients with their management. This will promote positive adherent behaviors and consequently effective management of the CKD population.

Conflict of interest: The authors declare no conflicts of interest.

Acknowledgements: I would like to acknowledge the College of Health Sciences, School of Nursing and Public Health of the University of KwaZulu-Natal.

\section{REFERENCES}

1. Fishbane S, Hazzan AD, Halinski C, Mathew AT. Challenges and opportunities in late-stage chronic kidney disease. Clinical kidney journal. 2015 Feb 1; 8(1):54-60.

2. GBD (2013) Mortality and Causes of Death Collaborators (2015) Global, regional, and 
national age-sex specific all-cause and causespecific mortality for 240 causes of death, 1990-2013: a systematic analysis for the global burden of disease study 2013. Lancet 385:117-171d oi : 10 . $1016 / \mathrm{S} 0140$ 6736(14)61682-2.

3. Singh S. Hypertension in chronic kidney disease. Clinical Queries: Nephrology. 2013 Mar 31; 2(1):15-22.

4. Barsoum RS. Burden of chronic kidney disease: North Africa. Kidney international supplements. 2013 May 31; 3(2):164-6.

5. Razmaria AA. Chronic Kidney Disease. Jama. 2016 May 24;315(20):2248-.

6. Bagga A, Srivastava RN. Acute Kidney Injury. Paediatric Nephrology. 2016 May 31:234.

7. Gillies K, Blakeman T, Lasserson D. Acute kidney injury. InnovAiT: Education and inspiration for general practice. 2016 Nov 4:1755738016675378.

8. Gergei I, Klotsche J, Woitas RP, Pieper L, Wittchen HU, Krämer BK, Wanner C, Mann JF, Scharnagl H, März W, Mondorf U. Chronic kidney disease in primary care in Germany. Journal of Public Health. 2016:1-8.

9. KDIGO CKD Work Group: KDIGO 2012 Clinical Practice Guideline for the Evaluation and Management of Chronic Kidney Disease. Kidney Inter. 2013 ;( Suppl. 3):1-150.

10. Ahlawat R, Tiwari P, D'Cruz S. Prevalence and predictors of medication non-adherence in patients of chronic kidney disease: Evidence from a cross sectional study. J Pharma Care Health Sys. 2016; 3(152):2376-0419.

11. Morton. G., Fontaine, D. K. (Eds.). Critical care nursing: a holistic approach. Philadelphia: Wolters Kluwer Health/Lippincott Williams \& Wilkins.2009.

12. Machek P, Jirka T, Moissl U, Chamney P, Wabel P. Guided optimization of fluid status in haemodialysis patients. Nephrology Dialysis Transplantation. 2009 Sep 30:gfp487.

13. Naicker S. End-stage renal disease in SubSaharan Africa. Kidney International Supplements. 2013 May 1;3(2):161-3.

14. Irwin, R.S., \& Rippe, J.M. (2012) Manual of intensive care medicine. Lippincott Williams \& Wilkins.

15. Richard CJ. Self-care management in adults undergoing haemodialysis. Nephrology Nursing Journal. 2006 Jul 1; 33(4):387.

16. Theofilou, P. (2012). The effect of sociodemographic features and beliefs about medicines on adherence to chronic kidney disease treatment. J Clin Res Bioethics, 3, 1-5.

17. J.A. Cramer, A. Roy, A. Burrell, et al. Medication compliance and persistence: terminology and definitions Value Health, 11 (2008), pp. 44-47

18. Sabaté E. Adherence to long-term therapies: evidence for action. World Health Organization;
2003.

19. Vlaminck H, Maes B, Jacobs A, Reyntjens S, Evers G. The dialysis diet and fluid non-adherence questionnaire: validity testing of a self-report instrument for clinical practice INFORMATION POINT: Kendall's Tau. Journal of clinical nursing. 2001 Sep 15; 10(5):707-15.

20. Kim Y, Evangelista LS, Phillips LR, Pavlish C, Kopple JD. The End-Stage Renal Disease Adherence Questionnaire (ESRD-AQ): testing the psychometric properties in patients receiving in-centrehaemodialysis. Nephrology nursing journal: journal of the American Nephrology Nurses' Association. 2010 Jul; 37(4):377.

21. Griva K, Lai AY, Lim HA, Yu Z, Foo MW, Newman SP. Non-adherence in patients on peritoneal dialysis: a systematic review. PLoS One. 2014 Feb 25;9(2):e89001

22. Hecking E, Bragg-Gresham JL, Rayner HC, Pisoni RL, Andreucci VE, Combe C, Greenwood R, McCullough K, Feldman HI, Young EW, Held PJ. Haemodialysis prescription, adherence and nutritional indicators in five European countries: results from the Dialysis Outcomes and Practice Patterns Study (DOPPS). Nephrology Dialysis Transplantation. 2004 Jan 1; 19(1):100-7.

23. Kutner NG, Zhang R, McClellan WM, Cole SA. Psychosocial predictors of non-compliance in haemodialysis and peritoneal dialysis patients. Nephrology Dialysis Transplantation. 2002 Jan 1; 17(1):93-9.

24. Leggat JE, Orzol SM, Hulbert-Shearon TE, Golper TA, Jones CA, Held PJ, Port FK. Noncompliance in haemodialysis: predictors and survival analysis. American Journal of Kidney Diseases. 1998 Jul 31; 32(1):139-45.

25. Bleyer AJ, Hylander B, Sudo H, Nomoto Y, de la Torre E, Chen RA, Burkart JM. An international study of patient compliance with haemodialysis. Jama. 1999Apr 7; 281(13):1211-3.

26. Sherman RA, Cody RP, Matera JJ, Rogers ME, Solanchick JC. Deficiencies in delivered haemodialysis therapy due to missed and shortened treatments. American journal of kidney diseases. 1994 Dec 1; 24(6):921-3.

27. Chironda, G, Manwere, A, Nyamakura, R, Chipfuwa, T. \& Bhengu, B. (2014). Perceived health status and adherence to haemodialysis by End Stage Renal Disease (ESRD) patients: A case of a central Hospital in Zimbabwe. IOSR Journal of nursing and health sciences. 2014, Volume 3 issue 1, pp22-31.

28. Schmid H, Hartmann B, Schiffl H. Adherence to prescribed oral medication in adult patients undergoing chronic haemodialysis: a critical review of the literature. European journal of medical research. 2009 Jun 14; 14(5): 185.

29. Hirth RA, Greer SL, Albert JM, Young EW, Piette JD. Out-of-pocket spending and medication adherence among dialysis patients in twelve 
countries. Health affairs. 2008 Jan 1; 27(1):89102.

30. Holley JL, DeVore CC. Why all prescribed medications are not taken: results from a survey of chronic dialysis patients. Advances in peritoneal dialysis. 2006; 22:162.

31. Magacho EJ, Ribeiro LC, Chaoubah A, Bastos MG. Adherence to drug therapy in kidney disease. Brazilian Journal of Medical and Biological Research. 2011 Mar; 44(3):258-62.

32. Lin CC, Liang CC. The relationship between health locus of control and compliance of haemodialysis patients. The Kaohsiung journal of medical sciences. 1997 Apr; 13(4):243-54.

33. Cleary DJ, Matzke GR, Alexander AC, Joy MS. Medication knowledge and compliance among patients receiving long-term dialysis. American journal of health-system pharmacy. 1995 Sep 1; 52(17):1895-900.

34. Kaplan B, Mason NA, Shimp LA, Ascione FJ. Chronic haemodialysis patients. Part I: Characterization and drug-related problems. Annals of Pharmacotherapy. 1994 Mar 1; 28(3):316-9.

35. Bame SI, Petersen N, Wray NP. Variation in haemodialysis patient compliance according to demographic characteristics. Social science \& medicine. 1993 Oct 1;37(8):1035-43.

36. Chironda G, Bhengu B. Engagement with Fluid and Dietary among Chronic Kidney Disease (CKD) in Selected Public Hospitals of KwaZuluNatal (KZN) Province, South Africa. Health Science Journal. 2016 Nov 1; 10(5).

37. Rambod M, Peyravi H, Shokrpour N, Sareban MT. Dietary and fluid adherence in Iranian haemodialysis patients. The health care manager. 2010 Oct 1;29(4):359-64.

38. Lindberg M, PRÜTZ KG, Lindberg P, Wikström B. Intradialytic weight gain and ultrafiltration rate in haemodialysis: lessons about fluid adherence from a national registry of clinical practice. Haemodialysis International. 2009 Apr $1 ; 13(2): 181-8$

39. O'Connor SM, Jardine AG, Millar K. The prediction of self-care behaviours in end-stage renal disease patients using Leventhal's SelfRegulatory Model. Journal of psychosomatic research. 2008 Aug 31; 65(2):191-200.

40. Barnett T, Li Yoong T, Pinikahana J, Si-Yen T. Fluid compliance among patients having haemodialysis: can an educational programme make a difference? Journal of Advanced Nursing. 2008 Feb 1; 61(3):300-6.

41. Kara B, Caglar K, Kilic S. Nonadherence with diet and fluid restrictions and perceived social support in patients receiving haemodialysis. Journal of Nursing Scholarship. 2007 Sep 1; 39(3):243-8.

42. Druse CL, Holdsworth M, Watson V, Przygrodzka F. Knowledge of dietary restrictions and the medical consequences of noncompliance by patients on haemodialysis are not predictive of dietary compliance. Journal of the American Dietetic Association. 2004 Jan 31; 104(1):35-41.

43. Casey J, Johnson V, McClelland P. Impact of stepped verbal and written reinforcement of fluid balance advice within an outpatient haemodialysis unit: a pilot study. Journal of Human Nutrition and Dietetics. 2002 Feb 1; 15(1):43-7.

44. Khalil AA, Darawad MW. Objectively measured and self-reported nonadherence among Jordanian patients receiving haemodialysis. Haemodialysis International. 2014 Jan 1; 18(1):95-103.

45. Chan YM, Zalilah MS, Hii SZ. Determinants of compliance behaviours among patients undergoing hemodialysis in Malaysia. PloS one. 2012 Aug 3; 7(8):e41362.

46. Kugler C, Vlaminck H, Haverich A, Maes B. Nonadherence with diet and fluid restrictions among adults having haemodialysis. Journal of Nursing Scholarship. 2005 Mar 1;37(1):25-9.

47. Lee SH, Molassiotis A. Dietary and fluid compliance in Chinese haemodialysis patients. International journal of nursing studies. $2002 \mathrm{Sep}$ 30; 39(7):695-704.

48. Liu H, Golin CE, Miller LG, Hays RD, Beck CK, Sanandaji S, Christian J, Maldonado T, Duran D, Kaplan AH, Wenger NS. A comparison study of multiple measures of adherence to HIV protease inhibitors. Annals of internal medicine. 2001 May 15; 134(10):968-77.

49. Curtin RB, Sitter DC, Schatell D, Chewning BA. Self-management, knowledge, and functioning and well-being of patients on haemodialysis. Nephrology Nursing Journal. 2004 Jul 1; 31(4):378.

50. Szczech LA, Kalayjian R, Rodriguez R, Gupta S, Coladonato J, Winston J. The clinical characteristics and antiretroviral dosing patterns of HIV-infected patients receiving dialysis. Kidney international. 2003 Jun 30; 63(6):2295301.

51. Testa A, Beaud JM. The other side of the coin: intradialytic weight gain as an index of good nutrition. American journal of kidney diseases. 1998 May 1; 31(5):830-4.

52. Lindberg M (2010) Excessive Fluid Overload among Haemodialysis Patients: Prevalence, Individual Characteristics and Self-regulation of Fluid Intake. Haemodialysis international 13: 181-188.

53. Holmberg B, Stegmayr BG. Cardiovascular conditions in haemodialysis patients may be worsened by extensive intradialytic weight gain. Haemodialysis International. 2009 Jan 1; 13(1):27-31.

54. Denhaerynck K, Manhaeve D, Dobbels F, Garzoni D, Nolte C, De Geest S. Prevalence and 
consequences of nonadherence to haemodialysis regimens. American Journal of Critical Care. 2007 May 1; 16(3):222-35.

55. Dean D, Cruz DN. We Use Permcaths Instead of Peritoneal Catheters for Acute Kidney Injury and Urgent-Start Dialysis. InSeminars in dialysis 2016 Jul 1 (Vol. 29, No. 4, pp. 260-262).

56. Lim HA, Yu Z, Kang AW, Foo MW, Griva K. The Course of Quality of Life in Patients on Peritoneal Dialysis: A 12-month Prospective Observational Cohort Study. International journal of behavioral medicine. 2016 Aug 1; 23(4):507-14.

57. Palmer BF. Opinion: Can Chronic Volume Overload Be Recognized and Prevented in Haemodialysis Patients? In Seminars in dialysis 2009 Sep 1 (Vol. 22, No. 5, pp. 489-491). Blackwell Publishing Ltd.

58. Moose MR, Kidd M. The dangers of rationing dialysis treatment: the dilemma facing a developing country. Kidney international. 2006 Sep 2; 70(6):1107-14.

59. Wanner C, Metzger T, Krane V. Lipid lowering in end-stage renal disease. Saudi Journal of Kidney Diseases and Transplantation. 2001 Jan 1; 12(1):3. 
Table 1: Methods of measuring adherence in Chronic Kidney Disease (CKD) patients

\begin{tabular}{lcl}
\hline Management modality & Method of measuring adherence \\
\hline Medication & Self-report \\
& $*$ Biological markers \\
Diet & Self-report \\
& & \\
& & Biological markers \\
Fluid & Self-report \\
& & Intradialytic weight gain (IDWG) \\
Dialysis & & Self-report missed dialysis \\
& & Self-report shortened dialysis \\
&
\end{tabular}

Table 2: Instruments for measuring adherence in Chronic Kidney Disease (CKD) patients

\begin{tabular}{ll}
\hline Name of instrument & Management modality \\
\hline $\begin{array}{l}\text { The Dialysis, Diet and Fluid non-adherence } \\
\text { Questionnaire (DDFQ) (2001) }\end{array}$ & Dialysis, Diet and fluid \\
$\begin{array}{l}\text { End Stage Renal Disease Adherence } \\
\text { Questionnaire (ESRD: AQ)(2010) }\end{array}$ & Diet, medication, fluid and dialysis \\
\hline
\end{tabular}


Table 3: Studies identified for dialysis adherence in Chronic Kidney Disease (CKD) patients

\begin{tabular}{|c|c|c|c|c|c|}
\hline Author, year & Sample & Measurement & Non adherence & Adherence & Country \\
\hline Sherman, 1994 & 860 & $\begin{array}{l}\text { Skipped } \\
\text { Shortened }\end{array}$ & $\begin{array}{l}5.1-7.9 \% \\
26.8-32.3 \%\end{array}$ & $\begin{array}{l}92.1-94.9 \% \\
67.7-73.2 \%\end{array}$ & USA \\
\hline $\begin{array}{l}\text { Leggat et al, } \\
1998\end{array}$ & 6251 & $\begin{array}{l}\text { Skipped } \\
\text { Shortened }\end{array}$ & $\begin{array}{l}8.5 \% \\
20.3 \%\end{array}$ & $\begin{array}{l}91.5 \% \\
79.7 \%\end{array}$ & USA \\
\hline $\begin{array}{l}\text { Bleyer et al, } \\
1999\end{array}$ & $\begin{array}{l}\text { Japan } 194 \\
\text { Sweden } \\
84\end{array}$ & Skipped & $\begin{array}{l}\text { Japan- } 0 \\
\text { Sweden- } 0\end{array}$ & $\begin{array}{l}\text { Japan- } 0 \\
\text { Sweden- } 0\end{array}$ & $\begin{array}{l}\text { Japan } \\
\text { Sweden }\end{array}$ \\
\hline $\begin{array}{l}\text { Kutner et al, } \\
2002\end{array}$ & 119 & $\begin{array}{l}\text { Skipped } \\
\text { Shortened }\end{array}$ & $\begin{array}{l}19 \% \\
31 \%\end{array}$ & $\begin{array}{l}81 \% \\
69 \%\end{array}$ & USA \\
\hline $\begin{array}{l}\text { Hecking et al, } \\
2004\end{array}$ & $\begin{array}{l}\text { France } \\
672 \\
\text { Germany } \\
571 \\
\text { Italy } 600 \\
\text { Spain } 576 \\
\text { UK } 620\end{array}$ & Skipped & $\begin{array}{l}\text { France }-0.3 \% \\
\text { Germany- } 0.9 \% \\
\text { Italy- } 8.8 \% \\
\text { Spain- } 6.6 \% \\
\text { UK }-12.6 \%\end{array}$ & $\begin{array}{l}\text { France-99.7\% } \\
\text { Germany } 99.1 \\
\% \\
\text { Italy- } 91.2 \% \\
\text { Spain- } 93.4 \% \\
\text { UK - 87.4\% }\end{array}$ & $\begin{array}{l}\text { France } \\
\text { Germany } \\
\text { Italy } \\
\text { Spain } \\
\text { UK }\end{array}$ \\
\hline $\begin{array}{l}\text { Chironda et al, } \\
2014\end{array}$ & 80 & $\begin{array}{l}\text { Skipped and } \\
\text { missed }\end{array}$ & $97 \%$ & $3 \%$ & Africa \\
\hline Griva et al, 2014 & & $\begin{array}{l}\text { Missed } \\
\text { Shortened } \\
\text { Self-report } \\
\text { Biological }\end{array}$ & $\begin{array}{l}2.5-53 \% \\
4-15 \% \\
2-40 \% \\
22-26 \%\end{array}$ & $\begin{array}{l}47-97.5 \% \\
85-96 \% \\
60-98 \% \\
74-78 \%\end{array}$ & Singapore \\
\hline
\end{tabular}


Table 4: Studies identified for medication adherence in Chronic Kidney Disease (CKD) patients

\begin{tabular}{|c|c|c|c|c|c|}
\hline Author, year & Sample & Medication & Non adherence & Adherence & Measurement \\
\hline $\begin{array}{l}\text { Bame et al, } \\
1993\end{array}$ & 1230 & $\begin{array}{l}\text { PB, AHT, } \\
\text { CAS }\end{array}$ & $50 \%$ & $50 \%$ & $\begin{array}{l}\text { Phosphorus > } \\
6.0 \mathrm{mg} / \mathrm{dl}\end{array}$ \\
\hline $\begin{array}{l}\text { Kaplan et al, } \\
1994\end{array}$ & 30 & $\mathrm{~PB}, \mathrm{AHT}$ & $67 \%$ & $33 \%$ & Self-report \\
\hline $\begin{array}{l}\text { Cleary et al, } \\
1995\end{array}$ & 51 & $\begin{array}{l}\text { AHT, PB, } \\
\text { CAS, VITS }\end{array}$ & $61 \%$ & $39 \%$ & $\begin{array}{l}\text { Phosphorus > } \\
5.5 \mathrm{mg} / \mathrm{dl} \& \\
\text { self-report }\end{array}$ \\
\hline $\begin{array}{l}\text { Lin \& } \\
\text { Liang, } 1997\end{array}$ & 86 & $\begin{array}{l}\text { PB } \\
\text { CAS }\end{array}$ & $\begin{array}{l}24 \% \\
61 \%\end{array}$ & $\begin{array}{l}76 \% \\
39 \%\end{array}$ & $\begin{array}{l}\text { Phosphorus > } \\
4.59 \mathrm{mg} / \mathrm{dl} \& \\
\text { self-report }\end{array}$ \\
\hline $\begin{array}{l}\text { Curtin et al, } \\
1999\end{array}$ & 135 & AHT \& PB & $73 \%$ & $27 \%$ & $\begin{array}{l}\text { Mems \& self- } \\
\text { report }\end{array}$ \\
\hline $\begin{array}{l}\text { Tornasello, } \\
2004\end{array}$ & 129 & $\mathrm{~PB}$ & $23 \%$ & $77 \%$ & $\begin{array}{l}\text { Phosphorus > } \\
5.5 \mathrm{mg} / \mathrm{dl} \text { and } \\
\text { self-report }\end{array}$ \\
\hline $\begin{array}{l}\text { Holley \& } \\
\text { Devore, } \\
2006\end{array}$ & 39 & AHT, PB & $21 \%$ & $79 \%$ & Self-report \\
\hline Hirth, 2008 & 5478 & $\begin{array}{l}\text { AHT, PB, } \\
\text { CAS }\end{array}$ & $3-29 \%$ & $71-97 \%$ & Self-report \\
\hline $\begin{array}{l}\text { Magacho, et } \\
\text { al, } 2011\end{array}$ & 149 & PB & $17.4 \%$ & $82.6 \%$ & Self-report \\
\hline
\end{tabular}

PB- Phosphate binders, AHT - Antihypertensive, CAS - Calcium supplements, VITS Vitamin 
Table 5: Studies identified for fluid adherence in Chronic Kidney Disease (CKD) population

\begin{tabular}{|c|c|c|c|c|c|}
\hline Author, year & Sample & Measurement & Non adherence & Adherence & Country \\
\hline $\begin{array}{l}\text { Bame et al, } \\
1993\end{array}$ & 1230 & IDWG & $49.5 \%$ & $51.5 \%$ & USA \\
\hline $\begin{array}{l}\text { Leggat et al, } \\
1998\end{array}$ & 6251 & IDWG & $9.7 \%$ & $90.3 \%$ & USA \\
\hline $\begin{array}{l}\text { Christensen, } \\
1995\end{array}$ & 57 & IDWG & $42 \%$ & $58 \%$ & USA \\
\hline $\begin{array}{l}\text { Casey et al, } \\
2002\end{array}$ & 21 & IDWG & $60 \%$ & $40 \%$ & UK \\
\hline $\begin{array}{l}\text { Vlamnick et al, } \\
2001\end{array}$ & 564 & SR & $72 \%$ & $28 \%$ & Belgium \\
\hline $\begin{array}{l}\text { Durose, et al } \\
2004\end{array}$ & 82 & IDWG & $23 \%$ & $77 \%$ & UK \\
\hline $\begin{array}{l}\text { Barnet et al, } \\
2007\end{array}$ & 26 & IDWG & $53 \%$ & $47 \%$ & Australia \\
\hline Kara et al, 2007 & 160 & SR & $68.1 \%$ & $31.9 \%$ & Turkey \\
\hline $\begin{array}{l}\text { Russel et al, } \\
2007\end{array}$ & 107 & IDWG & $40 \%$ & $60 \%$ & USA \\
\hline $\begin{array}{l}\text { O Connor et al, } \\
2008\end{array}$ & 73 & IDWG & $70 \%$ & $30 \%$ & UK \\
\hline $\begin{array}{l}\text { Lindberg et al, } \\
2009\end{array}$ & 4498 & IDWG & $30 \%$ & $70 \%$ & Sweden \\
\hline Chan et al, 2012 & Not stated & IDWG & $24.5 \%$ & $75.5 \%$ & Malaysia \\
\hline $\begin{array}{l}\text { Khalil, \& } \\
\text { Darawad, } 2014\end{array}$ & 90 & $\begin{array}{l}\text { IDWG } \\
\text { SR }\end{array}$ & $17 \%-80 \%$ & $20 \%-83 \%$ & Jordan \\
\hline $\begin{array}{l}\text { Chironda \& } \\
\text { Bhengu, } 2016\end{array}$ & 90 & $\begin{array}{l}\text { IDWG } \\
\text { SR }\end{array}$ & $89 \%$ & $11 \%$ & $\begin{array}{l}\text { South } \\
\text { Africa }\end{array}$ \\
\hline
\end{tabular}

IDWG - Intradialytic weight gain, SR - Self report 
Table 6: Studies identified for Dietary adherence in Chronic Kidney Disease (CKD) patients

\begin{tabular}{|c|c|c|c|c|c|}
\hline Author, year & Sample & Measurement & Non adherence & Adherence & Country \\
\hline Bame et al, 1993 & 1230 & $\begin{array}{l}\text { Potassium } \\
\text { Phosphorus }\end{array}$ & $\begin{array}{l}2 \% \\
50 \%\end{array}$ & $\begin{array}{l}98 \% \\
50 \%\end{array}$ & USA \\
\hline $\begin{array}{l}\text { Leggat et al, } \\
1998\end{array}$ & 6251 & Phosphorus & $22.1 \%$ & $77.9 \%$ & USA \\
\hline $\begin{array}{l}\text { Vlamnick et al, } \\
2001\end{array}$ & 564 & Self-report & $81.4 \%$ & $18.6 \%$ & Belgium \\
\hline $\begin{array}{l}\text { Durose et al, } \\
2004\end{array}$ & 82 & $\begin{array}{l}\text { Potassium } \\
\text { Phosphorus }\end{array}$ & $\begin{array}{l}4 \% \\
31 \%\end{array}$ & $\begin{array}{l}96 \% \\
69 \%\end{array}$ & $\begin{array}{l}\text { United } \\
\text { kingdom }\end{array}$ \\
\hline $\begin{array}{l}\text { Hecking et al, } \\
2004\end{array}$ & 3039 & $\begin{array}{l}\text { Potassium } \\
\text { Phosphorus }\end{array}$ & $\begin{array}{l}11.7 \% \\
23.8 \%\end{array}$ & $\begin{array}{l}88.3 \% \\
76.2 \%\end{array}$ & $\begin{array}{l}\text { France, } \\
\text { Germany, } \\
\text { Italy and } \\
\text { Spain }\end{array}$ \\
\hline $\begin{array}{l}\text { Kugler et al, } \\
2005\end{array}$ & 916 & Self-report & $81.4 \%$ & $18.6 \%$ & $\begin{array}{l}\text { Germany and } \\
\text { Belgium }\end{array}$ \\
\hline $\begin{array}{l}\text { Unruh, et al, } \\
2005\end{array}$ & 739 & $\begin{array}{l}\text { Phosphate } \\
\text { Potassium }\end{array}$ & $\begin{array}{l}33.3 \% \\
2 \%\end{array}$ & $66.7 \%$ & USA \\
\hline Kara et al, 2007 & 160 & Self-report & $58.1 \%$ & $41.9 \%$ & Turkey \\
\hline $\begin{array}{l}\text { Russel et al, } \\
2007\end{array}$ & 107 & $\begin{array}{l}\text { Phosphate } \\
\text { Albumin }\end{array}$ & $\begin{array}{l}68 \% \\
77 \%\end{array}$ & $\begin{array}{l}32 \% \\
23 \%\end{array}$ & USA \\
\hline Rambod, 2010 & $\begin{array}{l}\text { Not } \\
\text { stated }\end{array}$ & $\begin{array}{l}\text { Phosphate } \\
\text { Potassium } \\
\text { Protein }\end{array}$ & $\begin{array}{l}25.5 \% \\
5.5 \% \\
4.5 \%\end{array}$ & $\begin{array}{l}74.5 \% \\
94.5 \% \\
95.5 \%\end{array}$ & Iran \\
\hline $\begin{array}{l}\text { Lee and } \\
\text { Mollasiotis, } \\
2002\end{array}$ & 62 & $\begin{array}{l}\text { Potassium } \\
\text { Phosphate } \\
\text { Self-report }\end{array}$ & $\begin{array}{l}38.7 \% \\
56.5 \% \\
44 \%\end{array}$ & $\begin{array}{l}61.3 \% \\
43.6 \% \\
56 \%\end{array}$ & Hong Kong \\
\hline $\begin{array}{l}\text { Khalil, \& } \\
\text { Darawad, } 2014\end{array}$ & 90 & $\begin{array}{l}\text { Self- } \\
\text { reportpotassiu } \\
\text { m, phosphorus } \\
\text { blood urea } \\
\text { nitrogen }\end{array}$ & $17 \%-80 \%$ & $20 \%-83 \%$ & Jordan \\
\hline $\begin{array}{l}\text { Chironda \& } \\
\text { Bhengu, } 2016\end{array}$ & 90 & Self-report & $84 \%$ & $16 \%$ & South Africa \\
\hline
\end{tabular}


Table 7- Overall adherence rates to medication, diet, fluid and dialysis for Chronic Kidney Disease (CKD) patients

\begin{tabular}{|c|c|c|}
\hline Management Modality & Non adherence rate & Adherence rate \\
\hline Medication & $\begin{array}{l}3-80 \% \text { through self-report and } \\
\text { biological markers }\end{array}$ & $\begin{array}{l}20-97 \% \text { through self-report and } \\
\text { biological markers }\end{array}$ \\
\hline Fluid & $\begin{array}{l}30-80 \% \text { - self report } \\
10-60 \% \text { - interdialytic weight gain } \\
\text { (IDWG) }\end{array}$ & $\begin{array}{l}26-70 \% \text { - self report } \\
40-90 \% \text { - interdialytic weight gain } \\
\text { (IDWG) }\end{array}$ \\
\hline Diet & $\begin{array}{l}2-39 \% \text { - self report } \\
19-57 \% \text { - biological markers }\end{array}$ & $\begin{array}{l}61-98 \% \text { - self report } \\
19-57 \% \text { - biological markers }\end{array}$ \\
\hline Hemodialysis & $\begin{array}{l}0-35 \% \text {-skipping hemodialysis } \\
2-32 \% \text {-shortened hemodialysis }\end{array}$ & $\begin{array}{l}65-100 \% \text {-skipping hemodialysis } \\
68-98 \% \text {-shortened hemodialysis }\end{array}$ \\
\hline $\begin{array}{l}\text { Continuous ambulatory } \\
\text { peritoneal dialysis } \\
\text { (CAPD) }\end{array}$ & $\begin{array}{l}2.5-53 \% \text { - Missed PD exchanges } \\
4-15 \% \text { - Shortening PD exchages } \\
22-26 \% \text { - Biological markers }\end{array}$ & $\begin{array}{l}47-97.5 \% \text { - Missed PD exchanges } \\
85-96 \% \text { - Shortening PD exchanges } \\
74-78 \% \text { - Biological markers }\end{array}$ \\
\hline
\end{tabular}

Figure 1- Flow Chart of Search Strategy and Results

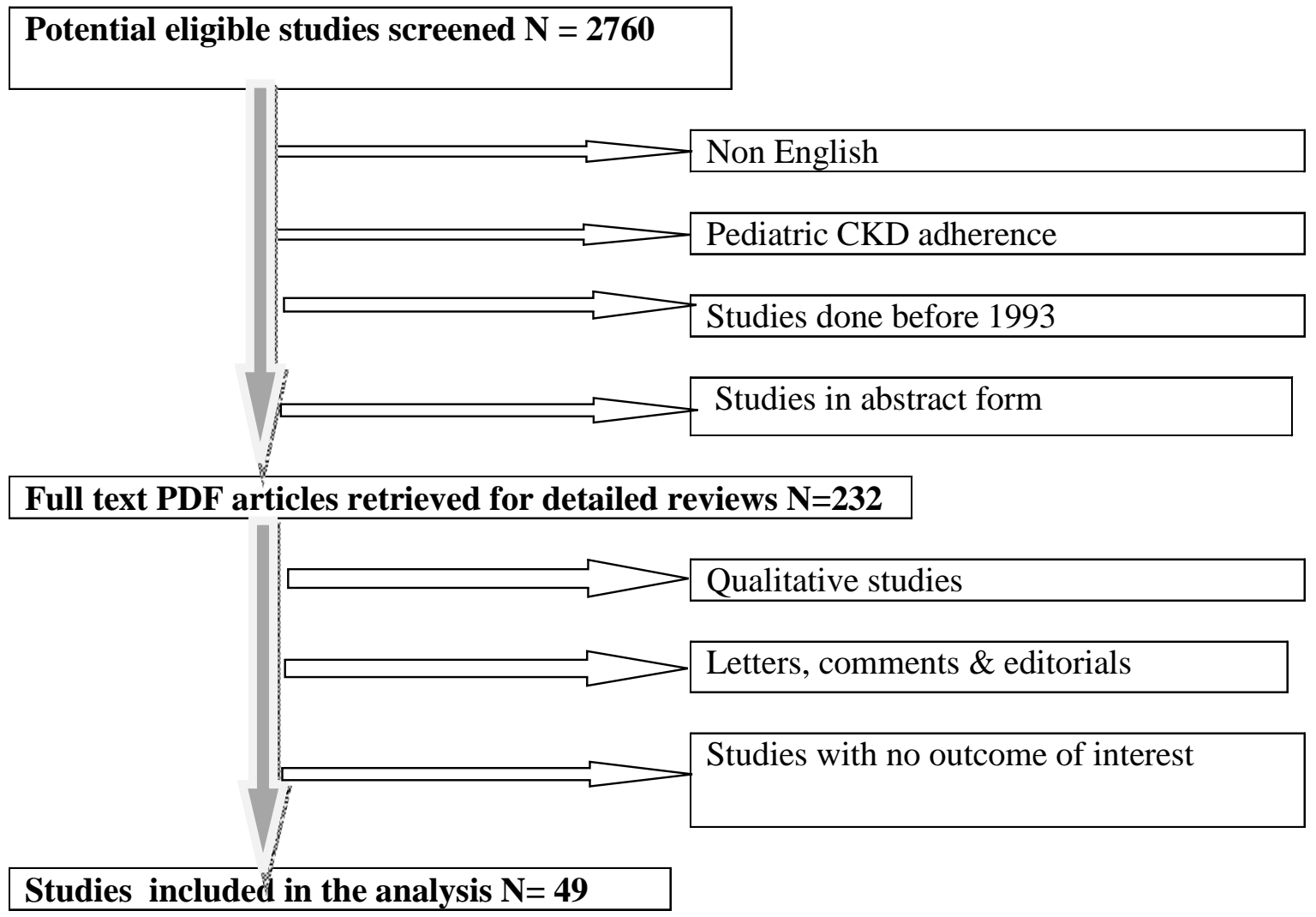

